\title{
PENGARUH PARTISIPASI MASYARAKAT DALAM KONDISI SANITASI DASAR PENGELOLAAN LIMBAH RUMAH TANGGA DI KAMPUNG SANITASI RAWA MEKAR JAYA, TANGERANG SELATAN
}

The Effect Of Community Participation In Basic Sanitation Conditions On Household Waste Management In Sanitation Village Rawa Mekar Jaya Selatan Tangerang

\author{
Maulida Khairunnisa, Arif Sumantri
}

Program Studi Kesehatan Masyarakat Fakultas IImu Kesehatan UIN Syarif Hidayatullah Jakarta maulidakhairunnisa9@gmail.com, 087877271876

\section{ABSTRACT}

Domestic waste generation in Indonesia was estimate at 71.1 ton if it wasn't manage properly. However, not all households had a good basic sanitation conditions and participation in basic sanitation of household waste management. Therefore, this research is aim to analyze the community participation in waste management in 'Kampung Sanitasi' Rawa Mekar Jaya, South Tangerang in 2020. This research was done by observation and using cross-sectional approach. Samples were 73 head of family in one household and were taken on November-Desember in 2020. This study was analyzed by using a Chi-Square analysis. The result showed that $56 \%$ of respondents had a low participation ability in waste management. At the level of confidence ( $\alpha$ ) $5 \%$ variable of open defection free conditions ( $p$-value=0.024; $O R=4.320)$, safety conditions for household solid waste ( $p$-value $=0.000 ; O R=280)$, and safety conditions for household liquid waste $(p$-value $=0.045 ; O R=4.488)$ were correlation with the ability of community participation in waste management. There were a correlation between analyze the potetial carrying capacity of the environment and the ability of community participation in waste management in 'Kampung Sanitasi'.

Keyword: Participation, Waste Management, Basic Sanitation

\section{ABSTRAK}

Timbulan limbah rumah tangga di Indonesia diperkirakan mencapai 71,1 ton jika tidak dikelola dengan baik. Namun, tidak semua rumah tangga memiliki kondisi sanitasi dasar dan partisipasi yang baik dalam pengelolaan limbah. Tujuan dari penelitian ini adalah untuk menganalisis pengaruh partisipasi masyarakat dalam kondisi sanitasi dasar pengelolaan limbah di Kampung Sanitasi Rawa Mekar Jaya, Tangerang Selatan Tahun 2020. Penelitian ini menggunakan desain studi cross sectional dengan jumlah responden sebanyak 73 kepala keluarga dalam satu KK. Penelitian ini dilakukan pada bulan November-Desember 2020. Penelitian ini dianalisis menggunakan uji chi-square. Hasil penelitian menunjukkan bahwa $56 \%$ responden memiliki kemampuan partisipasi rendah dalam pengelolaan limbah. Pada derajat kepercayaan (a) $5 \%$ variabel kondisi stop buang air besar sembarangan ( $p$-value $=0,024 ; O R=4,320$ ), kondisi pengamanan limbah padat rumah tangga ( $p$-value $=0,000 ; O R=280$ ), dan kondisi pengamanan limbah cair rumah tangga ( $p$-value $=0,045$; $\mathrm{OR}=4,488$ ) memiliki pengaruh yang signifikan dengan kemampuan partisiapasi masyarakat dalam pengelolaan limbah. Ada perbedaan signifikan antara kondisi sanitasi dasar terhadap kemampuan partisipasi masyarakat dalam pengelolaan limbah.

Kata Kunci: Partisipasi, Pengelolaan Limbah, Sanitasi Dasar

\section{PENDAHULUAN}

Limbah rumah tangga merupakan hasil kegiatan manusia yang berasal dari dapur, kamar mandi, cucian, limbah bekas industri manusia, dan kotoran manusia (Sunarsih, 2014). Timbulan limbah rumah tangga di Indonesia diperkirakan mencapai 71,1 ton pada tahun 2025 jika tidak terkelola dengan baik (Badan Pusat Statistik, 2018). Permasalahan ini erat kaitannya dengan pembangunan sosial ekonomi.

Pembangunan sosial ditandai dengan pertumbuhan penduduk di Indonesia yang diperkirakan mencapai 284 juta orang pada tahun 2025 (Badan Pusat Statistik, 2018). Selain itu, adanya perubahan pola konsumsi masyarakat mengarah pada kebiasan penggunaan produk sekali pakai masyarakat perkotaan. Pembangunan ekonomi ditandai peningakatan pendapatan suatu daerah (GDP). Berdasarkan data statistik, Indonesia masuk dalam kategori negara yang perekonomiannya terus membaik, sehingga timbulan limbah yang dihasilkan akan terus bertambah (Badan Pusat Statistik, 2018).

Permasalahan lingkungan akan timbul akibat limbah tidak dikelola dengan baik diantaranya tercemarnya air, tanah, dan udara. Berdasarkan data statistik, kualitas air sungai di Indonesia berada pada status tercemar berat $(51,01 \%)$ pada tahun 2018 , dan sekitar 2,7\% desa tercemar tanahnya. Emisi gas rumah kaca dari sektor limbah di Indonesia diperkirakan akan mencapai 2,6 miliar ton $\mathrm{CO}_{2} \mathrm{e}$ pada tahun 2050 (Badan Pusat Statistik, 2018).

Limbah rumah tangga juga berkontribusi pada kondisi sanitasi dasar layak. Rumah tangga dikatakan mencapai kondisi sanitasi dasar layak adalah ketika mampu memenuhi syarat minimum tiga pilar dalam sanitasi total berbasis masyarakat yakni, stop buang air besar sembarangan, pengamanan limbah padat rumah tangga, dan pengamanan limbah cair rumah tangga (Kementerian Kesehatan RI, 2008).

Kondisi sanitasi dasar layak pada provinsi terpadat ketiga di Indonesia dengan 
Jurnal Sulolipu : Media Komunikasi Sivitas Akademika dan Masyarakat

Vol. 21 No.2 2021

e-issn : 2622-6960, p-issn : 0854-624X

kepadatan penduduk $1.338 \mathrm{jiwa} / \mathrm{km}^{2}$ (Badan Pusat Statistik, 2019) baru mencapai 65,44\% (Badan Pusat Statistik, 2020). Secara garis besar $55 \%$ pengelolaan sampah rumah tangga di Banten pun tidak baik (Kementerian Kesehatan RI, 2019). Kota Tangerang Selatan dengan pertumbuhan ekonomi tertinggi di Pulau Jawa (7,35\%) (Badan Pusat Statistik, 2020) dan kepadatan penduduk sebesar $11.875 \mathrm{jiwa} / \mathrm{km}^{2}$ (Badan Pusat Statistik, 2019) mengalami masalah yang sama. Sebagian besar penduduk masih membuang limbah dari dapur $(67,9 \%)$ dan masih membuang limbah dari kamar mandi langsung ke got/kali/sungai (66,49\%) (Kementerian Kesehatan RI, 2019). Pada tahun 2019, dua dari sepuluh penyakit terbesar di Kota Tangerang Selatan adalah penyakit sistem pencernaan dan pernapasan akibat kondisi sanitasi dasar pengelolaan limbah yang buruk (Dinas Kesehatan Kota Tangerang Selatan, 2020).

Pengelolaan limbah yang tidak baik dapat memberikan kontribusi negatif pada lingkungan dan kesehatan, oleh karena itu dibutuhkan langkah penanganan. Penanganan limbah ini dalam Perpres Nomor 59 tahun 2017 yang merupakan implementasi Sustainable Development Goals (SDGs) di Indonesia, dimana dalam tujuan 6 salah satu targetnya meningkatnya akses terhadap sanitasi layak pada tahun 2019 menjadi 100\% serta pada tujuan 12 salah satu targetnya setiap negara secara substansial mengurangi produksi limbah melalui pencegahan, pengurangan, daur ulang, dan penggunaan kembali (Kementerian Perencanaan Pembangunan Nasional RI, 2017).

Regulasi dalam penanganan limbah tertuang dalam UU nomor 18 tahun 2008 tentang pengelolaan sampah, serta PP nomor 66 tahun 2014 tentang upaya penyelenggaraan kesehatan lingkungan untuk mencegah terjadinya penyakit. Berdasarkan Kepmenkes RI Nomor 852/Menkes/SK/IX/2008, pemerintah menargetkan setiap individu dan komunitas mempunyai akses terhadap sarana sanitasi dasar dan setiap rumah mengelola limbah padat serta cairnya dengan benar.

Menumbuhkan kepedulian terhadap lingkungan dalam hal pengelolaan limbah perlu dilakukan oleh masyarakat sebagai penerima dampak langsung. Partisipasi aktif masyarakat dibutuhkan untuk keseimbangan dan keserasian antara pembangunan sosial, ekonomi, dan lingkungan (Faturochman \&
Widanigrum, 2019). Berdasarkan hasil penelitian kualitatif pada kawasan perkotaan kumuh di Malang, diketahui bahwa terjadi peningkatan partisipasi masyarakat pada aspek pengelolaan limbah dalam bentuk pikiran dan materi atas dasar keinginan untuk ikut serta dalam partisipasi kegiatan mendatang (Ramadani, et al., 2016).

Kampung Sanitasi adalah sebuah kampung permukiman warga yang diresmikan menjadi kampung percontohan dalam penerapan perilaku kesehatan dalam upaya penyelenggaraan kesehatan lingkungan pada tahun 2019 oleh Walikota Tangerang Selatan. Dalam mewujudkan misi Kota Tangerang Selatan untuk mencipatakan kota layak huni yang berwawasan lingkungan, adanya kampung sanitasi ini diharapkan dapat menjadi pintu masuk permukiman berwawasan lingkungan. Berdasarkan hasil wawancara dengan kepala RT 03 RW 03, masyarakat memiliki potensi partisipasi yang baik jika terdapat pemicu.

Berdasarkan fakta yang telah diuraikan di atas, penelitian ini bertujuan untuk menganalisis kondisi sanitasi dasar terhadap kemampuan partisipasi masyarakat dalam pengelolaan limbah rumah tangga di Kampung Sanitasi Kelurahan Rawa Mekar Jaya, Tangerang Selatan.

\section{METODE}

\section{Desain, tempat dan waktu}

Penetian ini merupakan penelitian kuantitatif menggunakan metode deskriptif analitik dengan rancangan cross sectional. Penelitian ini dilakukan di Kampung Sanitasi RT 03 RW 03, Kelurahan Rawa Mekar Jaya Tangerang Selatan. Penelitian ini dilakukan pada bulan November sampai dengan Desember tahun 2020.

\section{Jumlah dan Cara Pengambilan Subjek}

Sampel penelitian ini adalah kepala keluarga dalam satu KK yang betempat tinggal di Kampung Sanitasi RT 03 RW 03 Rawa Mekar Jaya, Tangerang Selatan. Subjek dalam penelitian ini berjumlah 73 kepala keluarga. Pengambilan subjek dalam penelitian ini dilakukan dengan menggunakan purposive sampling.

\section{Jenis dan Cara Pengumpulan Data}

Dilakukan pengamatan pada kondisi stop buang air besar sembarangan, pengamanan 
Jurnal Sulolipu : Media Komunikasi Sivitas Akademika dan Masyarakat

Vol. 21 No.2 2021

e-issn : 2622-6960, p-issn : 0854-624X

limbah padat rumah tangga, dan pengamanan limbah cair rumah tangga yang memiliki pengaruh pada kemampuan partisipasi masyarakat dalam pengelolaan limbah. Data diperoleh melalui penyebaran kuesioner dan observasi menggunakan lembar checklist.

\section{Pengolahan dan Analisis Data}

Pengolahan data dilakukan menggunakan program komputerisasi statistik dengan tahapan editing, coding, entry, dan cleaning data. Kemudian dianalisis menggunakan uji chi-square.

\section{HASIL}

Kampung Sanitasi secara administratif berada di wilayah RT 003/003 Kelurahan Rawa Mekar Jaya Kota Tangerang Selatan pada wilayah kerja Puskesmas Rawabuntu dengan kepadatan penduduk $\pm 59,7 \mathrm{Jiwa} / \mathrm{Ha}$ (Kelurahan Rawa Mekar Jaya, 2019). Pembangunan pemberdayaan masyarakat di kampung sanitasi ini masih pada tahap perencanaan. Terkait dengan pendapat masyarakat tentang kampung sanitasi, masyarakat berpendapat bahwa kampung sanitasi adalah suatu bentuk lingkungan permukiman yang baik yang dapat dijadikan contoh bagi wilayah permukiman lain $(89 \%)$.

Diketahui bahwa karakteristik subjek penelitian sebagian besar berjenis kelamin laki-laki (92\%), berusia lebih dari 50 tahun $(38 \%)$, berpendidikan SMA/sederajat $(47 \%)$, dan bekerja sebagai wiraswasta (33\%).

Menurut ketua RT 03, adanya pembangunan kampung sanitasi dalam hal sanitasi dasar pengelolaan limbah secara mandiri di masa yang akan datang dapat mencegah penyakit berbasis lingkungan dan meningkatkan derajat kesehatan masyarakat. Kemampuan partisipasi masyarakat dalam pengelolaan limbah tergolong rendah (56\%). Untuk potensi daya dukung lingkungan, kondisi stop buang air besar sembarangan belum memenuhi syarat (77\%), kondisi pengamanan limbah rumah tangga belum memenuhi syarat $(60 \%)$, serta kondisi pengamanan limbah cair sudah memenuhi syarat $(78 \%)$.

Berdasarkan hasil penelitian, responden yang memiliki kondisi stop buang air besar sembarangan tidak memenuhi syarat dan partisipasi rendah sebanyak 36 orang (64\%). Hasil uji chi-square pada derajat kepercayaan (a) $5 \%$ ada pengaruh yang signifikan antara kemampuan partisipasi responden dalam pengelolaan limbah dengan kondisi stop buang air besar sembarangan di kampung sanitasi ( $p$ value $=0,024 ; \mathrm{OR}=4,320$ ).

Responden yang memiliki kondisi pengamanan limbah padat tidak memenuhi syarat dan partisipasi rendah sebanyak 40 orang $(91 \%)$. Hasil uji chi-square pada derajat kepercayaan (a) 5\% ada pengaruh yang signifikan antara kemampuan partisipasi responden dalam pengelolaan limbah dengan kondisi pengamanan limbah padat di kampung sanitasi $(p$-value $=0,000$; $\mathrm{OR}=280$ ).

Responden yang memiliki kondisi pengamanan limbah cair memenuhi syarat dan partisipasi tinggi sebanyak 29 orang $(51 \%)$. Hasil uji chi-square pada derajat kepercayaan (a) $5 \%$ ada pengaruh yang signifikan antara kemampuan partisipasi responden dalam pengelolaan limbah dengan kondisi pengamanan limbah ciar di kampung sanitasi ( $p$-value $=0,045$; $\mathrm{OR}=4,488$ ).

\section{PEMBAHASAN}

Partisipasi masyarakat dalam pengelolaan limbah akan mempengaruhi kondisi stop buang air besar sembarangannya. Ketika terdapat partisipasi aktif masyarakat dalam pengelolaan limbah kondisi kondisi jamban menjadi lebih baik menjadi dalam bentuk kloset, sudah tidak ditemukan kotoran manusia di sekitar masyarakat, masyarakat menjadi lebih sadar akan menjaga kebersihan dan kesehatan dengan membuang air besar di jamban sehat (Nugraha, 2015).

Kondisi stop buang air besar tidak memenuhi syarat dan partisipasi masyarakat rendah dapat memberikan dampak negatif pada kesehatan dan lingkungan. Tinja bayi yang dibuang begitu saja bersama popok dapat menjadi tempat berkembang biak berbagai macam virus, termasuk hepatitis $B$ dan polio dari vaksin yang diberikan kepada bayi baru lahir. Selain itu, fungsi tanah sebagai penyedia berbagai sumber daya dan habitat bagi makhluk hidup akan menurun (Meseldzija, et al., 2013).

Partisipasi masyarakat dalam pengelolaan limbah yang rendah di kampung sanitasi dapat disebabkan kesadaran masyarakat akan pentingnya pencapaian indikator-indikator kondisi stop buang air besar sembarangan masih kurang dan kurangnya informasi yang didapatkan dari tokoh masyarakat, media masa, serta tenaga 
Jurnal Sulolipu : Media Komunikasi Sivitas Akademika dan Masyarakat

Vol. 21 No.2 2021

e-issn : 2622-6960, p-issn : 0854-624X

kesehatan (Alhassan \& Anyarayor, 2018). Masyarakat pun masih belum mandiri dalam merubah kondisi stop buang air besar sembarangan dan masih menuntut bantuan fisik dari pemerintah (Indriyani, et al., 2016).

Kondisi pengamanan limbah padat yang tidak memenuhi syarat menunjukkan rendahnya partisipasi masyarakat dalam pengelolaan limbah padat. Masyarakat kampung sanitasi belum memilah limbah yang akan dibuang ( $81 \%)$, belum ada upaya mengolah limbah padat organiknya menjadi kompos (81\%) dan limbah padat anorganiknya menjadi barang bernilai ekonomis dengan prinsip 3R (reduce, reuse, recycle) $(79 \%)$, serta masih terlihat limbah padat berserakan di halaman rumah $(57 \%)$.

Limbah padat yang tidak terkelola dapat menurunkan kualitas lingkungan dan kesehatan masyarakat. Pembusukan sampah organik yang tercampur dengan sampah anorganik dan pembakaran sampah menyumbang pada emisi gas rumah kaca karena gas metana $\left(\mathrm{CH}_{4}\right)$ dan gas karbondioksida $\left(\mathrm{CO}_{2}\right)$ yang dihasilkannya (Njoku, et al., 2019). Dampak penurunan kualitas udara ini dapat menyebabkan penyakit seperti flu, iritasi mata, kelelahan, serta ISPA (Njoku, et al., 2019) (Prasetyoputra \& Irianti, 2018).

Ketika masyarakat memiliki partisipasi aktif dalam mengumpulkan, mengambil, hingga mengelola limbah padat menjadi kompos ataupun barang bernilai ekonomis dengan prinsip 3R dapat meningkatkan kualitas lingkungan dan ekonomi masyarakat (Sulistiyorini, et al., 2018). Kompos yang dihasilkan masyarakat dapat meningkatkan hasil perkebunan dan pertanian sehingga perekonomian masyarakat pun meningkat (Sarasati, 2016).

Adanya partisipasi aktif masyarakat dalam pengelolaan limbah dengan memilah bahan organik dan minyak yang tidak dibuang langsung ke saluran bak cuci piring terbukti dapat mengurangi zat pencemar dalam air limbah (Aryantie, et al., 2017). Sementara, ketika partisipasi masyarakat rendah tebukti dengan kondisi sungai yang keruh dan berbau serta selokan-selokan warga yang macet sehingga terjadi pencemaran lingkungan (Prayogo, 2016).

Dalam hal ini, terlihat bahwa terdapat sinergisitas antara sosial masyarakat, kondisi lingkungan, serta ekonomi masyarakat. Sinergisitas inilah yang dibutuhkan dalam mewujudkan tujuan pembangunan berkelanjutan. Dalam perspektif islam, partisipasi masyarakat dalam menjaga lingkungan merupakan kewajiban (Shihab, 2000).

Adanya peran serta atau partisipasi masyarakat dalam pengelolaan limbah, maka di dalamya terdapat nilai ukhuwah islamiyah. Nilai ukhuwah merupakan nilai islami yang melambangkan hubungan persaudaraan akibat adanya rasa cinta berdasarkan akidah dan iman untuk membentuk suatu bangunan yang kokoh. Dalam hal pengelolaan limbah nilai ukhuwah ini dapat diwujudkan melalu gotongi royong untuk memperbaiki lingkungan dan meningkatkan kualitas lingkungan karena manusia adalah Khalifah Fi al-Ardi, yang memiliki tanggung jawab untuk menjaga bumi. Adanya nilai ukhuwah yang tertanam dalam masyarakat menjadi pondasi yang kuat dalam mewujudkan kualitas hidup yang baik (Anshori, 2016).

\section{KESIMPULAN}

Ada perbedaan signifikan antara potensi daya dukung lingkungan (kondisi stop buang air besar sembarangan, pengamanan limbah padat rumah tangga, dan pengamanan limbah cair rumah tangga) terhadap kemampuan partisipasi masyarakat dalam pengelolaan limbah di kampung sanitasi.

\section{SARAN}

Dalam upaya penyelenggaraan kesehatan lingkungan di kampung sanitasi disarankan kepada masyarakat kampung sanitasi untuk meningkatkan partisipasi dan kondisi sanitasi dasar dalam pengelolaan limbah sebagai potensi daya dukung lingkungan. Kepada Puskesmas Rawabuntu disarankan untuk melakukan edukasi dan pembinaan secara menyeluruh terkait dampak pencemaran lingkungan akibat tidak mengelola limbah, serta memanfaatkan potensi/peluang daya dukung lingkungan dan kemampuan partisipasi masyarakat untuk dikembangkan. 
Jurnal Sulolipu : Media Komunikasi Sivitas Akademika dan Masyarakat

Vol. 21 No.2 2021

e-issn : 2622-6960, p-issn : 0854-624X

\section{DAFTAR PUSTAKA}

Alhassan, A. \& Anyarayor, B. K., 2018. Determinants of adoption of open defecation-free (ODF) innovations: A case study of Nadowli-Kaleo district, Ghana. Journal of Development and Communication Studier, p. Vol. 5 No. 2.

Anshori, C. S., 2016. Ukhuwah Islamiyah Sebagai Fondasi Terwujudnya Organisasi yang Mandiri dan Profesional. Jurnal Pendidikan Agama Islam Ta'lim , 14(1), pp. 116-125.

Aryantie, M. H., Purwati, S. U. \& Pitalokasari, O. D., 2017. KUALITAS LIMBAH DOMESTIK DAN PARTISIPASI MASYARAKAT YANG PEDULI LINGKUNGAN DI PERUMAHAN PERMATA DEPOK KLASTER MIRAH 1 DAN 2. Prosiding Seminar Nasional Teknologi Pengelolaan Limbah $X V$, pp. ISSN 1410 - 6086.

Badan Pusat Statistik, 2018. Statistik Lingkungan Hidup Indonesia 2018 'Pengelolaan Sampah di Indonesia. Jakarta: Badan Pusat Statistik.

Badan Pusat Statistik, 2019. Kepadatan Penduduk Menurut Kabupaten/Kota. Jakarta: BPS.

Badan Pusat Statistik, 2019. Kepadatan Penduduk Menurut Provinsi. Jakarta: BPS.

Badan Pusat Statistik, 2020. Persentase Rumah Tangga yang Memiliki Akses Terhadap Layanan Sanitasi Layak dan Berkelanjutan (40\% Bawah), Menurut Provinsi. [Online] Available at: Bps.go.id [Accessed 15 April 2020].

Badan Pusat Statistik, 2020. Tinjauan Regional Berdasarkan PDRB Kabupaten/Kota 2015-2019, $\begin{array}{lllll}\text { Buku } & 2 & \text { Pulau Jawa-Bali. } & \text { [Online] }\end{array}$ Available $\quad$ at: https://www.bps.go.id/publication/download.html?nrbvfeve=YzBINTNIOWlzNTNiMWJhZTVmYz g1N2Nk\&xzmn=aHR0cHM6Ly93d3cuYnBzLmdvLmlkL3B1YmxpY2F0aW9uLzIwMjAvMTAvMD UvYzBINTNIOWIzNTNiMWJhZTVmYzg1N2NkL3RpbmphdWFuLXJIZ2lvbmFsLWJIcmRhc2Fya 2FuLXBkcmlta2FidXBhdGVuLWtvdGEt

[Accessed 30 January 2021].

Dinas Kesehatan Kota Tangerang Selatan, 2020. 10 Penyakit Terbesar tahun 2019. Tangerang Selatan: Dinkes Tangsel.

Faturochman \& Widanigrum, A., 2019. Konsep dan Indikator Daya Tampung Sosial. [Online] Available at: file:///C:/Users/Maulida/Downloads/KonsepDayaTampungSosial.pdf [Accessed 29 January 2021].

Indriyani, Y., Yuniarti \& Latif, R. V. N., 2016. KAJIAN STRATEGI PROMOSI KESEHATAN SANITASI TOTAL BERBASIS MASYARAKAT (STBM) KELURAHAN TIRTO KECAMATAN PEKALONGAN BARAT KOTA PEKALONGAN. Unnes Journal of Public Health, pp. Voleme 5, No. 3.

Kelurahan Rawa Mekar Jaya, 2019. Monografi Kelurahan Rawa Mekar Jaya Tahun 2019. Tangerang Selatan: Kelurahan Rawa Mekar Jay.

Kementerian Kesehatan RI, 2008. Keputusan Menteri Kesehatan Republik Indonesia Nomor 852/MENKES/SK/ix/2008.

[Online]

Available

at:

http://ciptakarya.pu.go.id/plp/upload/peraturan/Kepmen Kes No 852 Tahun 2008 -

strategi nasional STBM.pdf

[Accessed 29 Januari 2021].

Kementerian Kesehatan RI, 2019. Laporan Provinsi Banten Riskesdas 2018. 1st ed. Jakarta: Lembaga Penerbit Badan Penelitian dan Pengembangan Kesehatan (LPB). 
Jurnal Sulolipu : Media Komunikasi Sivitas Akademika dan Masyarakat

Vol. 21 No.2 2021

e-issn : 2622-6960, p-issn : 0854-624X

Kementerian Perencanaan Pembangunan Nasional RI, 2017. Ringkasan Metadata Indikator Tujuan Pembangunan Berkelanjutan Indonesia. Jakarta: BAPPENAS.

Meseldzija, J., Poznanovic, D. \& Frank, R., 2013. Assessment of the differing environmental impacts between reusable and disposable diapers. Dufferin Research, pp. - .

Njoku, P. O., Edokpayi, J. N. \& Odiyo, J. O., 2019. Health and Environmental Risks of Residents Living Close to a Landfill: A Case Study of Thohoyandou Landfill, Limpopo Province, South Africa. International Journal of Enviromental Research and Public Health, p. 16.

Nugraha, M. F., 2015. Dampak Program Sanitasi Total Berbasis Masyarakat (STBM) Pilar Pertama di Desa Gucialit Kecamatan Gucialit Kabupaten Lumajang. Jurnal Kebijakan dan Manajemen Publik, p. Vol. 3 No. 2.

Prasetyoputra, P. \& Irianti, S., 2018. OPEN BURNING OF HOUSEHOLD SOLID WASTE AND CHILD RESPIRATORY HEALTH: EVIDENCE FROM INDONESIA. Jurnal Ekologi Kesehatan, pp. 123-134.

Prayogo, H., 2016. PARTISIPASI PENGRAJIN BATIK DALAM PENGELOLAAN LIMBAH DI WILAYAH INDUSTRI BATIK KELURAHAN JENGGOT KECAMATAN PEKALONGAN SELATAN. Skripsi Universitas Negeri Semarang, pp. - .

Ramadani, A. K., Sasongko, I. \& Setijawan, A., 2016. PENINGKATAN PARTISIPASI MASYARAKAT PADA PERMUKIMAN KUMUH DI KELURAHAN KOTALAMA, KOTA MALANG. Jurnal ITN.

Sarasati, C., 2016. PENGELOLAAN SAMPAH SWAKELOLA SEBAGAI BENTUK PARTISIPASI MASYARAKAT (KAMPUNG SUKUNAN, KELURAHAN BANYURADEN, SLEMAN YOGYAKARTA). MODUL, p. Vol 16 No. 2.

Shihab, M. Q., 2000. Tafsir Al-Mishbah Volume 1. 1st ed. Tangerang Selatan: Lentera Hati.

Sulistiyorini, N. R., Darwis, R. S. \& Gutama, A. S., 2018. PARTISIPASI MASYARAKAT DALAM PENGELOLAAN SAMPAH DI LINGKUNGAN MARGALUYU KELURAHAN CICURUG. Share Social Work Jurnal, p. Volume 5 Halaman!.

Sunarsih, E., 2014. Konsep Pengolahan Limbah Rumah Tangga dalam Upaya Pencegahan Pencemaran Lingkungan. Jurnal Ilmu Kesehatan Masyarakat, V(3), pp. 162-167. 
Jurnal Sulolipu : Media Komunikasi Sivitas Akademika dan Masyarakat

Vol. 21 No.2 2021

e-issn : 2622-6960, p-issn : 0854-624X

\section{Tabel 1}

Pengaruh Potensi Daya Dukung Lingkungan dengan Kemampuan Partisipasi Masyarakat dalam Pengelolaan Limbah Rumah Tangga di Kampung Sanitasi Rawa Mekar Jaya

\begin{tabular}{|c|c|c|c|c|c|}
\hline \multirow[t]{2}{*}{ No } & \multirow[t]{2}{*}{$\begin{array}{c}\text { Potensi Daya } \\
\text { Dukung Lingkungan }\end{array}$} & \multicolumn{2}{|c|}{$\begin{array}{l}\text { Kemampuan Partisipasi Masyarakat } \\
\text { dalam Pengelolaan Limbah }\end{array}$} & \multirow[t]{2}{*}{$\begin{array}{c}\text { OR } \\
(95 \% \mathrm{Cl})\end{array}$} & \multirow[t]{2}{*}{$\begin{array}{c}\mathrm{P}- \\
\text { value }\end{array}$} \\
\hline & & Tinggi & Rendah & & \\
\hline 1 & $\begin{array}{l}\text { Kondisi stop buang } \\
\text { air besar } \\
\text { sembarangan tidak } \\
\text { memenuhi syarat }\end{array}$ & 20 orang $(36 \%)$ & 36 orang $(64 \%)$ & $\begin{array}{l}4,320 \\
(1,330-14,023)\end{array}$ & 0,024 \\
\hline 2 & $\begin{array}{l}\text { Kondisi } \\
\text { pengamanan limbah } \\
\text { padat tidak } \\
\text { memenuhi syarat }\end{array}$ & 4 orang $(9 \%)$ & 40 orang $(91 \%)$ & $\begin{array}{l}280 \\
(29,69-2640,39)\end{array}$ & 0,000 \\
\hline 3 & $\begin{array}{l}\text { Kondisi } \\
\text { pengamanan limbah } \\
\text { cair memenuhi } \\
\text { syarat }\end{array}$ & 29 orang $(51 \%)$ & 28 orang (49\%) & $\begin{array}{l}4,488 \\
(1,154-17,461)\end{array}$ & 0,045 \\
\hline
\end{tabular}

